\title{
THE IMPACT OF ORGANISATIONAL RESTRUCTURING ON PERCEPTIONS OF TRUSTWORTHINESS
}

\author{
NEVILLE BEWS \\ Department of Sociology \\ Rand Afrikaans University \\ TINA UYS \\ Department of Sociology \\ Rand Afrikaans University
}

\begin{abstract}
An opportunity recently arose in a South African organisation currently undergoing drastic structural changes to assess the effects of these changes on the trust relationship between employees and those to whom these employees report. Two studies form the focus of this article. The first one was undertaken prior to the announcement of the restructuring programme. Some 13 months after the restructuring was announced and 10 months after it had commenced, a similar study focusing on trust was undertaken. In this paper the major findings of the two studies on the trust relationship in the organisation are compared.
\end{abstract}

\section{OPSOMMING}

Die geleentheid het onlangs ontstaan om die effek van hierdie veranderinge op die vertrouensverhouding tussen werknemers en diegene aan wie hulle rapporteer binne ' $n$ Suid-Afrikaanse organisasie wat tans drastiese strukturele veranderinge ondergaan, te beoordeel. Hierdie artikel fokus op twee studies. Die eerste een is onderneem net voor die aankondiging van die herstruktureringsprogram. Ongeveer 13 maande na die herstrukturering aangekondig is en tien maande na dit ' $n$ aanvang geneem het, is ' $n$ soortgelyke studie oor die vertrouensverhouding onderneem. In hierdie artikel word die belangrikste bevindings van die twee studies met betrekking tot die vertrouensverhouding vergelyk en die resultate bespreek.

The need to investigate the phenomenon of trust has been highlighted in recent years (Dibben, 2000; Kramer \& Tyler, 1996) and, in the last decade, trust has been the focus of renewed attention, largely brought about by organisations' responding to globalisation and the changing nature of work. These responses seem to be affecting trust on three fronts (Rossouw \& Bews, 2001). Firstly, globalisation has introduced a high degree of diversity and, despite some of the advantages that diversity brings with it (Thomas, 1996), is also inclined to dilute trust as levels of familiarity decrease. In this sense Brenkert (1998b) refers to the need for commonality and Powell (1996) to the usefulness of kinship, professional bonds and community in the formation of trust. Secondly, a decrease in jobs, which is occurring on an international scale (Andrew Levy \& Associates, 2000; BBC News, 1999; Cleary, 1997; Denny \& Treanor, 1998; Howard, 1996; Kyoko, 1996; Webster, 1995), has led to increased insecurity amongst employees on all levels (Brenkert, 1998a; Howard, 1996) and there have been claims that the trust gap has widened (Horton \& Reid, 1991; Reina \& Reina, 1999; Shaw, 1997). Thirdly, these new organisational forms, which are much flatter and team and project driven, have resulted in an increased need for organisational trust as a means of securing and maintaining a competitive market advantage (Crandall \& Wallace, 1998; Lewicki \& Bunker, 1996; Powell, 1996). All of this makes it important to develop a deeper understanding of the dynamics of trust within an organisational setting.

Although it has been suggested that these developments have had a negative impact on organisational trust and that the trust gap between employers and employees is widening, there is little empirical research available to either support or refute these claims. Mishra and Spreitzer (1998) have indicated that survivor responses to downsizing differ in that these responses may be either positive, neutral or negative, and are dependent on how survivors believe the organisational change will affect them. If survivor responses to organisational change differ, then it is quite possible that the effects of organisational change on intraorganisational trust will also differ.

Requests for copies should be addressed to: T Uys, Departement of Sociology,

RAU, PO Box 524, Auckland Park, 2006. E-mail: bewsco@netactive.co.za
A series of studies, undertaken by the authors, provided an ideal opportunity to empirically examine the effects of organisational restructuring on trust as regards the perceptions of trustworthiness amongst employees and their direct, first-line supervisor or manager. This research, undertaken in a South African financial institution, extends back to 1996 and examines the relationship between trustworthiness, trust and organisational restructuring.

Although these studies go back to 1996, the major focus in this paper is on a comparison of the results of the 1999 study and the study undertaken in 2000. The focus is on these two studies because the 1999 research was undertaken prior to the company's embarking on a radical restructuring exercise, one of the aims of which was to cut costs by significantly reducing the staff complement of the company, while the second study, undertaken in 2000, occurred after this restructuring had commenced. This provided an opportunity to assess the impact of restructuring on organisational trust. This paper examines the impact of the restructuring and its effects on perceptions of trustworthiness between employees and those to whom these employees report at the company, both prior to and during organisational restructuring. In this sense, the aim of this paper, albeit a minor one, is to explore the dynamics of trust in a specific organisational setting in an attempt to improve our understanding of these dynamics.

Accordingly, in the remainder of this paper the concepts of trust and trustworthiness will be explored on the theoretical level to provide a background to this study of trust. Next the methodology employed in the study will be described. The more pertinent research results will then be presented and the findings analysed. Finally, commentary on these findings will be provided, the limitations of the study will be considered and suggestions for further research will be proposed.

The phenomenon of trust

Before defining the concepts of trust and trustworthiness, certain preconceptions about these concepts require clarification. Firstly, the issue of context needs some attention. It is becoming increasingly clear that any definition of trust must 
take note of the context in which it is constructed. As Hay (In this issue) points out, context, although critical to the understanding of trust, is an often-neglected aspect that needs careful noting. For our purposes then, the phenomenon of "trust" will be defined in an organisational setting, and in terms of a bi-party relationship between employees and those to whom these employees report directly.

Mayer, Davis and Schoorman (1995) argue that trust entails risk, as one or more parties make themselves vulnerable to the actions or non-actions of another or others. They also distinguish between trust and other concepts such as co-operation, confidence and predictability, pointing out that what is lacking in all three concepts is vulnerability and risk. Risk, they argue, is apparent in an active willingness to place trust as opposed to the passive intent of showing trust, which would make trust somewhat shallow. For instance, risk is not manifest in a passive indication of trust in a surgeon but rather in the active decision to undergo the surgical procedure. Risk alone, however, is insufficient for our purpose, as that would restrict trust to the intention of not harming another.

There are certain moral commitments attached to an employment relationship, moving it onto a slightly higher level than one based purely on economical grounds. In an employeremployee relationship there is, on the one hand, a responsibility to act in the interest of the employer at all times. On the other, there is an equal responsibility to consider the employee's interests. Consequently, trust in the workplace functions on a reciprocal basis and tends to carry with it a positive intention of acting in another's interests, thus distinguishing it from confidence, co-operation and reliance, all of which are more passive in nature. Soule (1998) provides a more in-depth discussion in this regard and argues that the employment relationship is rather deeper than a mere market transaction. In this sense it could be argued that trust in the employer-employee relationship often carries with it an element of caring, as Soule (1998, p. 249) puts it, "...a positive moral responsibility", which in this study is referred to as benevolence.

Finally, the distinction between trust and trustworthiness needs to be considered. Brenkert (1998b) argues that trust is based on common values or aims and entails the result of a judgment while trustworthiness is an evaluative process. Accordingly, the trusting party (trustor) will, based on her or his perceptions of the trustworthiness of the focus of trust (trustee), make a judgment and decide either to place or avoid placing trust in the trustee. Consequently, it could be argued that trust is the outcome of a process of evaluation, based on various elements, through which the focus of trust is assessed for perceived trustworthiness. In this sense trustworthiness is measured by means of certain facilitators and is compared against trust, which is measured as a separate dimension on a separate scale.

Against the background of the above discussion, and for the purposes of this study, trust is defined as: The willingness of the trustor (an employee), based on an evaluative process, to expose her/himself to risk when relying on the trustee (a manager/supervisor) to act in her or his interests, even when unable to monitor the actions of the trustee. Trustworthiness is defined as an evaluative process governing the degree of trust, which, at an elevated level, may intensify trust and at a minimal level, may evoke distrust.

The focus of this study is on those elements by means of which the trustor evaluates the trustworthiness of the trustee (which we will refer to as the facilitators of trustworthiness) and on a separate dimension designed to measure trust. The term "facilitator" is used to encapsulate the role that these elements play, facilitating meaning to make something more achievable, more fluent. These facilitators thus play an active role in lubricating or, in their more negative form, impeding the flow of trust. We also refer to these facilitators with respect to trustworthiness rather than trust per se as it is these facilitators that the trustor uses to evaluate the trustworthiness of the focus of trust when deciding how much trust to put in the trustee.

A literature scan uncovered numerous "antecedents", "characteristics" or "dimensions" of trust (for instance see Bews, 1999). Based on this scan and in order to keep consistency with the other studies undertaken at the company (Bews, 2000), we elected to remain with the following five facilitators of trustworthiness:

- Benevolence,

- Competency,

- Integrity,

- Personality factors and

- Openness,

the functions of which will now briefly be described.

Benevolence: refers to a concern for another in that it goes beyond not taking advantage of the vulnerability of that other to taking a more active interest in her or his well-being. Mayer et al (1995) refer to benevolence as an antecedent of trust and, in testing the model of Mayer et al, Engelbrecht and Cloete (2000) find empirical support for it.

Competency: relates to an ability, on both the technical and managerial levels, to wield influence in a specific domain (Mayer et al, 1995), thus making some positive difference for the trustor (Davis, Mayer \& Schoorman, 1995).

Integrity: is the fair and consistent application of a set of moral and ethical principles, acceptable to both trustor and trustee, which increase predictability and reliability, thus introducing greater equity. Both Barber (in Husted, 1998) and Mishra (1996) refer to reliability, consistency, dependability and credibility, all of which can be captured under integrity.

Personality factors: are what have been referred to as the "Big Five" (Martins, Watkins, Von der Ohe \& De Beer, 1997; Robbins, 1997) and include:

i) Agreeableness (good-naturedness, cooperativeness and courteousness);

ii) Conscientiousness (persistence, determination, hard work, dependability and propensity towards achievement);

iii) Emotional stability (being calm, enthusiastic, free from anxiety, depression and insecurity);

iv) Extroversion (sociability, friendliness and talkativeness) and

v) Openness to experience or resourcefulness (broadmindedness, creativity, imagination, artistic sensitivity and intellectual ability).

Openness: refers to a flow of information on two levels, the first of which concerns that information that is necessary to get a job done, while the second operates at a much deeper level and is of a more personal nature between trustor and trustee. Mishra (1996) warns of the danger of too great a degree of openness at the second level, which could, at times, be hurtful. Openness beyond what is appropriate in a particular situation may be more harmful than beneficial as it may result in perceptions of insincerity, which in turn are likely to erode trust.

It is proposed that, depending on contextual factors which may influence the perceived importance of each facilitator, the trustor evaluates the trustworthiness of the trustee via an interrelationship of the above six facilitators. In previous research (Bews, 2000; Engelbrecht \& Cloete, 2000) it was found that there is a significantly positive relationship $(p<0.01)$ between the facilitators of trustworthiness and trust. Bews's research referred to all six facilitators as discussed above while Engelbrecht and Cloete empirically tested the model of Mayer et al (1995) and consequently focused on ability, benevolence and integrity. In this study each of the facilitators of trustworthiness, 
as described above, are measured on separate scales, as are the dimensions of trust, the management of change and the unfolding of change.

It is further postulated that, during periods of organisational restructuring, the intensity of the relationship between employees and their first-line management will not necessarily reflect the relationship between these employees and higher levels of management within the organisation. Consequently, although employees may perceive their immediate supervisor or manager to be trustworthy, they may not necessarily be inclined to place trust in top management.

\section{Research questions and hypotheses}

Considering the above discussion and the seemingly contradictory responses to downsizing as cited by Mishra and Spreitzer (1998), the question as to the effects of organisational restructurings on intra-organisational trust arises. With this in mind the following hypotheses and research questions are formulated:

\section{Hypotheses:}

Hypothesis 1: There is a statistically significant difference in means between respondents in 1999, prior to the restructuring at the company, when compared with 2000, after the restructuring had been announced and had commenced, in respect of the levels of benevolence, competency, integrity, personality factors and openness, as well as the levels of trust in the person to whom they report.

Hypothesis 2: There is a statistically significant relationship between employees' level of trust in the person to whom they report and the extent to which they believe that the restructuring is well managed and the extent to which they believe that the restructuring will be beneficial to the company.

Hypothesis 3: There is a statistically significant correlation between employees' trust in first-line management (interpersonal trust) and their trust in top management at the company (generalised trust).

These hypotheses lead to the following research questions.

- What is the effect of restructuring on perceptions of trust between employee and first-line management in the company?

- What is the direction and level of trust between employees and executive management during the restructuring?

The research method utilized in this study will now be described.

\section{METHOD}

\section{Background to the change process}

In October 1999 the company embarked on an extensive communication process and executive management addressed all staff throughout the company. This was done by means of a series of "road shows". At these "road shows" the extent of the proposed restructuring was indicated, namely that the staff complement was to be reduced from 1235 employees to between 600 and 800.

Between October 1999 and November 2000 certain functional areas, such as finance, were restructured, affecting some 30 employees countrywide. Although these changes were rather limited, compared with what lay ahead, it is possible that they had some effect on the data collected in this study. By the time this paper was being written these changes had accelerated and a number of people had either been retrenched or faced a very uncertain future at the company. From a scientific point of view it would have been much more informative to have undertaken the study after the change had accelerated; unfortunately this was not practical for various reasons, not the least of which was the attitude at that point of management towards such a study.

\section{Profile of respondents}

Questionnaires distributed to all 1044 employees at the company produced $585(56,03 \%)$ responses. Of these respondents, $48 \%$ had been with the company for more than 10 years, $64,5 \%$ were between 24 and 45 years of age, $80 \%$ had an education equivalent to or higher than 12 years of schooling, $56,8 \%$ were female $29,7 \%$ reported their home language to be Afrikaans while 51,3\% indicated that it was English.

Given the background to the change process, this biographical data is probably an accurate reflection of developments that occurred at the company between the two surveys. The lower response rate in 2000 is probably largely due to certain employees' feeling reluctant to indicate their opinions at a time when job security was under threat. This deduction is made for two reasons. Firstly, in both surveys a memo signed by the Managing Director of the company to remind employees to return their questionnaire was sent out three weeks after the questionnaires had been distributed. In 1999, when this memo was sent out, the response rate had already reached $68 \%$ while in 2000 it had only reached $39 \%$. Secondly, during the 2000 survey, a number of employees approached one of the researchers and indicated their reluctance to participate in a survey that evaluated their trust in their immediate supervisor at a time when they would be applying for positions within the new company structure.

\section{Procedure}

In the 1999 study the method of triangulation was employed and data was collected by quantitative and qualitative techniques. This resulted in quantitative data being collected by means of a self-administered questionnaire and qualitative data being collected by means of:

- Interviews (semi-structured interviews)

- Direct observation (participant observation)

- Document analysis, and

- Maintaining a journal of events for the duration of the study.

The company subsequently began a vigorous restructuring programme and management required that a survey, again in the form of a self-administered questionnaire, be undertaken to help assess the initial impact of this restructuring. This gave rise to an opportunity to re-apply the original self-administered questionnaire, with certain modifications in an effort to meet management's requirements, and to assess the impact of the restructuring on intra-organisational trust.

To achieve this, exactly the same research strategy employed in the first study (the self-administered questionnaire) was used in the second study. However, it must be noted that the opportunistic nature of this research limited it to the selfadministered questionnaire. As one of the researchers was employed at the company and was therefore in a position to gather some data by means of the participant observation method, some qualitative data could also be collected, notwithstanding the limitations of this position.

In 1999 a 56-item questionnaire with a five-point Likert-type scale was used. This questionnaire, designed to measure all five facilitators of trustworthiness as listed above, as well as a separate scale, trust, based on the scale developed by Mayer et al (1995), were distributed to all staff at the company. In 2000, the same 56-item questionnaire, with the addition of 19 items designed to measure staff perceptions of (a) the management of change and (b) the unfolding of change at the company, was applied.

Although exactly the same distribution and collection strategy was used in both studies the response rates differed. In 1999, 
there were 897 responses, which amounted to a return rate of $75 \%$, while in 2000 , there were 585 responses, which amounted to a return rate of $56 \%$, a reduction of $19 \%$ when compared against the 1999 return rate. It is important to note that between the two surveys the overall staff complement at the company had been reduced by $14,5 \%$ as a direct result of the restructuring; this resulted in a much lower total number of responses. This, however, should not have affected the return rate. The possible effect of changes at the company between the two surveys and their effect on the results of this study must also be noted and kept in mind when analysing and interpreting these results.

It should also be remembered that a certain percentage of employees completed both the 1999 and 2000 questionnaires but their responses cannot be linked due to the anonymity of the research instrument. Data was statistically analysed by means of the Statistical Package for the Social Sciences (SPSS).

\section{Development of scales}

An item and factor analysis was undertaken on both sets of data and, to determine the reliability of the scales, the coefficient alpha was calculated in each case. In respect of the survey undertaken in 2000, two further scales were identified and the coefficient alpha was also calculated for each of these scales. The results of these calculations are illustrated in table 1.

TABLE 1

RELIABILITY OF THE SCALES

\begin{tabular}{lccc}
\hline \multicolumn{1}{c}{ Scales } & $\begin{array}{c}\text { No. of } \\
\text { items }\end{array}$ & $\begin{array}{c}\text { Coefficient } \boldsymbol{\alpha} \\
\mathbf{1 9 9 9}\end{array}$ & $\begin{array}{c}\text { Coefficient } \boldsymbol{\alpha} \\
\mathbf{2 0 0 0}\end{array}$ \\
\hline Scale A1 - Benevolence & 5 &, 930 &, 934 \\
Scale A2 - Competency & 6 &, 835 &, 795 \\
Scale A3 - Integrity & 5 &, 836 &, 787 \\
Scale A4 - Personality factors & 5 &, 831 &, 835 \\
Scale A5 - Openness & 8 &, 883 &, 896 \\
Scale B1 - Trust & 11 &, 936 &, 937 \\
Scale C1 - Management of change & 12 & na &, 935 \\
Scale C2 - Unfolding of change & 7 & na &, 840 \\
\hline
\end{tabular}

\section{RESULTS}

\section{Comparison between 1999 and 2000}

T-tests for equality of means were applied to the data. It was found that there was a significant difference (p-values $<0,05$ ) in the levels of benevolence, integrity and personality factors between 1999 and 2000 .

A comparison of the means of each scale as illustrated in table 2 indicates that all three scales had a greater tendency towards the positive side in 2000 than they did in 1999.

The general level of trust in the immediate supervisor during 2000 is shown by histogram 1 .
TABLE 2

EVALUATION OF THE FACILITATORS OF TRUSTWORTHINESS AND TRUST, $1999 \& 2000$

\begin{tabular}{|c|c|c|c|c|c|}
\hline Scales & $\begin{array}{c}\text { Mean } \\
1999\end{array}$ & $\begin{array}{c}\text { Mean } \\
2000\end{array}$ & Difference & $t(d f)$ & p-value \\
\hline $\begin{array}{l}\text { Scale A1 - } \\
\text { Benevolence }\end{array}$ & 3,31 & 3,55 & $-0,24$ & $-5,870(896,01)$ & $<0,001$ * \\
\hline $\begin{array}{l}\text { Scale A2 - } \\
\text { Competency }\end{array}$ & 3,58 & 3,62 & $-0,04$ & $-0,975(1282,29)$ & ,344 \\
\hline $\begin{array}{l}\text { Scale A3 - } \\
\text { Integrity }\end{array}$ & 3,34 & 3,57 & $-0,23$ & $-5,640(1390)$ & $<0,001$ * \\
\hline $\begin{array}{l}\text { Scale A4 - } \\
\text { Personality factors }\end{array}$ & 3,37 & 3,64 & $-0,27$ & $-7,087(988,65)$ & $<0,001$ * \\
\hline Scale A5 - Openness & 3,40 & 3,41 & $-0,01$ & $-0,257(1371)$ & 0,797 \\
\hline Scale B1 - Trust & 3,52 & 3,53 & $-0,01$ & $-0,389(1382)$ & 0,698 \\
\hline
\end{tabular}

* statistically significant

Figure 1 Scale B1-Trust

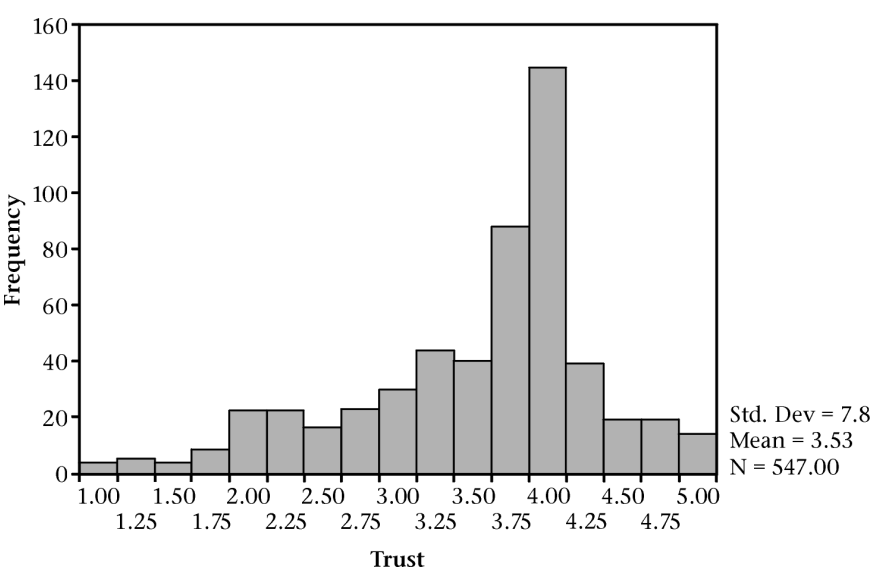

Despite the fact that certain of the facilitators of trustworthiness were significantly more positive in 2000 than they were in 1999 , the dimension "trust" showed no significant improvement. Considering the dynamics of trust as described above, an improvement in any of the facilitators of trustworthiness would be expected to have affected trust. The fact that this did not occur in this study may indicate that these facilitators of trustworthiness actually have less of an influence on trust than was originally believed.

Another reason may relate to the fact that the dynamics of trust are highly complicated and the change that occurred in respect of individual facilitators was not strong enough to have had an overall influence on trust.

\section{The effects of restructuring on trust}

Two scales, C1 and C2, were developed in an attempt to measure employees' perceptions of the restructuring that had taken place at the company by the time of the survey (see table 1). Scale $\mathrm{C} 1$ measured how employees perceived the change to be managed at the company while the second scale dealt with perceptions of how positively change was unfolding at that point. The results of these two scales indicate a tendency towards a normal distribution, with most responses remaining rather neutral as illustrated in histograms 2 and 3 below. 
Figure 2 SCALE C1-Management OF Change

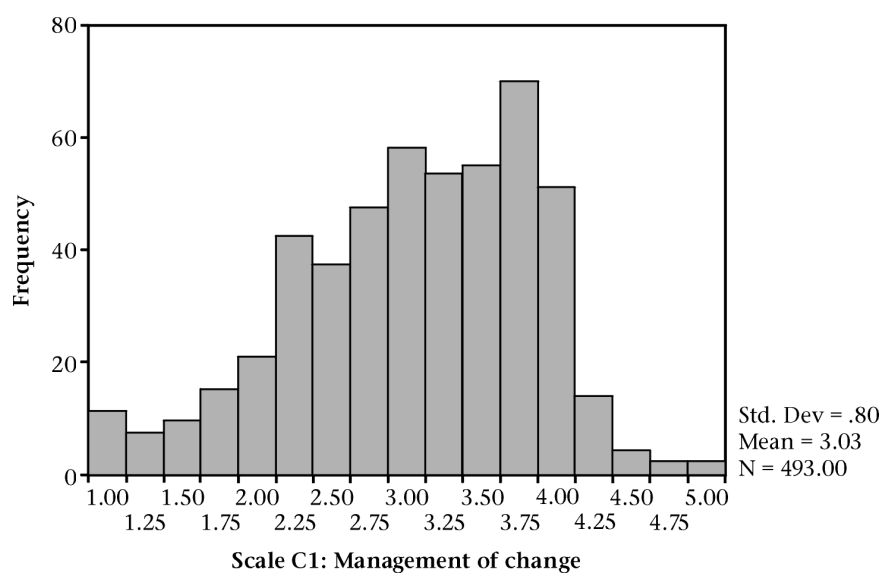

Figure 3 SCALE C2-Unfolding OF Change

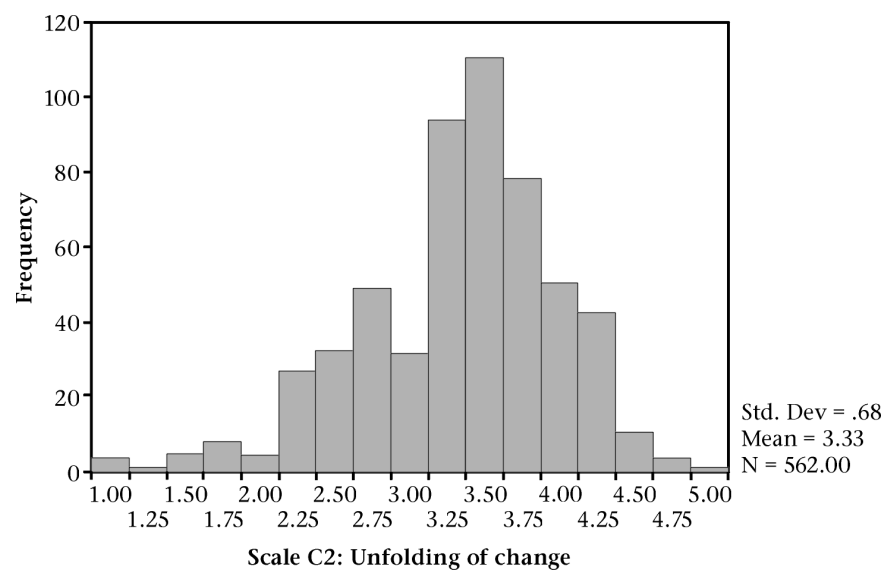

It was further established, by means of the Pearson product moment correlation coefficient, that a statistically significant positive relationship $(\mathrm{p}<0,001)$ exists between scale B1-Trust and both scales C1-Management of change and C2-Unfolding of change. The results of the correlation coefficients are provided in table 3.

TABLE 3

RELATIONSHIP BETWEEN TRUST AND ORGANISATIONAL CHANGE

\begin{tabular}{lccc}
\hline & B1-trust & $\begin{array}{c}\text { C1-management } \\
\text { of change }\end{array}$ & $\begin{array}{c}\text { C2-unfolding } \\
\text { of change }\end{array}$ \\
\hline B1-trust Pearson correlation & 1,000 &, $389^{* *}$ &, $320^{* *}$ \\
Sig. (2-tailed) & &, 000 &, 000 \\
$\mathrm{~N}$ & 547 & 474 & 534 \\
C1-management of change &, $387^{* *}$ & 1,000 &, $753^{* *}$ \\
Pearson correlation & & &, 000 \\
Sig. (2-tailed) &, 000 & & 486 \\
N & 474 & 493 & 1,000 \\
C2-unfolding of change &, $320^{* *}$ &, $752^{* *}$ & \\
Pearson correlation & & & \\
Sig. (2-tailed) &, 000 &, 000 & 562 \\
N & 534 & 486 & \\
\hline
\end{tabular}

** Correlation is significant at the 0,01 level (2-tailed)
Although it was initially expected that a high degree of restructuring would have a negative impact on employees' perceptions of the trustworthiness of their first-line supervisor/manager, this is not necessarily the case, considering the results as presented above. It is quite possible that employees appreciate that most of those to whom they report are as vulnerable to the restructuring of the company as they themselves are. If this is indeed the case, then it is also quite possible that in some respects the restructuring of the company actually acted as a bonding agent between employees and their first-line supervisors.

Such an argument is strengthened if one considers that it was with respect to the facilitators benevolence, integrity and personality factors that there was a more positive response in 2000 than in 1999, prior to the restructuring. These facilitators are probably more inclined to reflect a much deeper element of trustworthiness than competency and openness are. It has been suggested (Bews, 2000) that although both competence and openness are important factors of trustworthiness they are both limited to a more passive role.

Whereas very low levels of openness and competency are likely to have a negative impact on trust, at a very high level both openness and competency are unlikely to have a proportionally greater effect on perceptions of trustworthiness and consequently on trust. In fact, it seems that too high a degree of openness may at times be detrimental to perceptions of trustworthiness (Mishra, 1996). Consequently, it is quite possible that trust operates on a much broader basis than any of the facilitators would in isolation.

Both these findings, as discussed above, must also be considered in the light of occurrences at the company at the time that the survey was undertaken and in terms of the work undertaken by Mishra and Spreitzer (1998, p. 567). Mishra and Spreitzer cite research that indicates that in some cases survivors are energized and see restructuring as a career opportunity. The uncertainty at the company may have added to this and respondents may also have been ultra sensitive in responding to some of the survey questions. The findings of this research may therefore support Mishra and Spreitzer's argument, at least in some respects.

\section{Comparison of trust in direct supervisor and top management}

The Chi-square test for independence was applied and it was found that there was a statistically significant relationship $(p<0,001)$ between respondents' trust in their immediate supervisor (their inter-personal trust) and their trust in top management (their generalised trust). This is illustrated in table 4 .

Table 4 shows that there is a tendency for the level of employees' trust in their direct supervisor to correspond with their trust in top management. However, if one looks at the overall results it is evident that $69,2 \%$ of respondents trusted their immediate supervisor, while only $36,4 \%$ trusted top management. It is also interesting to note that $57,7 \%$ of those who trusted their immediate supervisor did not trust top management or were neutral, which indicates an inverse relationship. 
TABLE 4

RELATIONSHIP BETWEEN TRUST IN DIRECT SUPERVISOR AND TOP MANAGEMENT

\begin{tabular}{|c|c|c|c|c|}
\hline \multirow{2}{*}{$\begin{array}{c}\text { Trust in direct } \\
\text { supervisor (item } 41 \text { ) }\end{array}$} & \multicolumn{3}{|c|}{ Trust in top management (item 49) } & \multirow[t]{2}{*}{ Total } \\
\hline & Low & Medium & High & \\
\hline Low Count & 42 & 16 & 18 & 76 \\
\hline$\%$ within Item 41 & $55,3 \%$ & $21,1 \%$ & $23,7 \%$ & $100 \%$ \\
\hline \% within Item 49 & $24,6 \%$ & $8,2 \%$ & $8,6 \%$ & $13,2 \%$ \\
\hline Medium Count & 37 & 42 & 23 & 102 \\
\hline$\%$ within Item 41 & $36,3 \%$ & $41,2 \%$ & $22,5 \%$ & $100 \%$ \\
\hline \%within Item 49 & $21,6 \%$ & $21,4 \%$ & $11,0 \%$ & $17,7 \%$ \\
\hline High Count & 92 & 138 & 169 & 399 \\
\hline$\%$ within Item 41 & $23,1 \%$ & $34,6 \%$ & $42,4 \%$ & $100,0 \%$ \\
\hline \%within Item 49 & $53,8 \%$ & $70,4 \%$ & $80,5 \%$ & $69,2 \%$ \\
\hline Total Count & 171 & 196 & 210 & 577 \\
\hline$\%$ within Item 41 & $29,6 \%$ & $34,0 \%$ & $36,4 \%$ & $100,0 \%$ \\
\hline \multirow[t]{2}{*}{ \% within Item 49} & $100,0 \%$ & $100,0 \%$ & $100,0 \%$ & $100,0 \%$ \\
\hline & & Value & $\mathrm{df}$ & $\begin{array}{c}\text { Asymp. } \\
\text { Sig. (2-sided) }\end{array}$ \\
\hline \multicolumn{2}{|c|}{ Pearson Chi-square } & $42,164^{\mathrm{a}}$ & 4 & ,000 \\
\hline \multicolumn{2}{|c|}{$\mathrm{N}$ of valid cases } & 577 & & \\
\hline
\end{tabular}

a 0 cells $(, 0 \%)$ have expected count less than 5 . The minimum expected count is 22,52

This tendency is further illustrated by the differences in levels of trust amongst the various grades. Details are provided in tables 5 and 6.

TABLE 5

TRUST IN DIRECT SUPERVISOR ACCORDING TO GRADE OF EMPLOYEE

\begin{tabular}{lcccc}
\hline \multirow{2}{*}{$\begin{array}{c}\text { Grade in } \\
\text { company }\end{array}$} & \multicolumn{2}{c}{ My immediate supervisor is trustworthy } & \multirow{2}{*}{ Total } \\
\cline { 2 - 4 } & Low & Medium & High & \\
\hline Grade 4\&5 Count & 3 & 8 & 45 & 56 \\
\% within grade & $5,4 \%$ & $14,3 \%$ & $80,4 \%$ & $100,0 \%$ \\
\% within trust & $4,2 \%$ & $8,3 \%$ & $12,0 \%$ & $10,3 \%$ \\
Grade 6\&7 Count & 18 & 22 & 116 & 156 \\
\% within grade & $11,5 \%$ & $14,1 \%$ & $74,4 \%$ & $100,0 \%$ \\
\% within trust & $25,0 \%$ & $22,9 \%$ & $31,0 \%$ & $28,6 \%$ \\
Grade 8\&10 Count & 51 & 66 & 213 & 330 \\
\% within grade & $15,5 \%$ & $20,0 \%$ & $64,5 \%$ & $100,0 \%$ \\
\% within trust & $70,8 \%$ & $68,8 \%$ & $57,0 \%$ & $60,9 \%$ \\
Total $\quad$ Count & 72 & 96 & 374 & 542 \\
\% within grade & $13,3 \%$ & $17,7 \%$ & $69,0 \%$ & $100,0 \%$ \\
\% within trust & $100,0 \%$ & $100,0 \%$ & $100,0 \%$ & $100,0 \%$ \\
\hline
\end{tabular}

Pearson Chi-square $=9.316, \mathrm{df}=4, \mathrm{p}$-value $=0.027$ (one-tailed)

This result shows a clear trend for those in the higher grades (grades 4 and 5) to have more trust in their direct supervisor, who also tends to be part of top management, than those in lower grades. This trend is also illustrated in table 6 .
TABLE 6

TRUST IN TOP MANAGEMENT ACCORDING TO GRADE OF EMPLOYEE

\begin{tabular}{|c|c|c|c|c|}
\hline \multirow{2}{*}{$\begin{array}{l}\text { Grade in } \\
\text { company }\end{array}$} & \multicolumn{3}{|c|}{ Top management can be trusted } & \multirow{3}{*}{$\begin{array}{c}\text { Total } \\
56\end{array}$} \\
\hline & Low & Medium & High & \\
\hline Grade $4 \& 5$ Count & 14 & 12 & 30 & \\
\hline$\%$ within grade & $25,0 \%$ & $21,4 \%$ & $53,6 \%$ & $100,0 \%$ \\
\hline Trust \% within & $8,5 \%$ & $6,6 \%$ & $15,2 \%$ & $10,3 \%$ \\
\hline Grade $6 \& 7$ Count & 48 & 53 & 55 & 156 \\
\hline$\%$ within grade & $30,8 \%$ & $34,0 \%$ & $35,3 \%$ & $100,0 \%$ \\
\hline Trust $\%$ within & $29,1 \%$ & $29,1 \%$ & $27,8 \%$ & $28,6 \%$ \\
\hline Grade $8 \& 10$ Count & 103 & 117 & 113 & 333 \\
\hline$\%$ within grade & $30,9 \%$ & $35,1 \%$ & $33,9 \%$ & $100,0 \%$ \\
\hline Trust $\%$ within & $62,4 \%$ & $64,3 \%$ & $57,1 \%$ & $61,1 \%$ \\
\hline Count & 165 & 182 & 198 & 545 \\
\hline$\%$ within grade & $30,3 \%$ & $33,4 \%$ & $36,3 \%$ & $100,0 \%$ \\
\hline \% within V49 & $100,0 \%$ & $100,0 \%$ & $100,0 \%$ & $100,0 \%$ \\
\hline
\end{tabular}

Pearson Chi-square $=8,451, \mathrm{df}=4, \mathrm{p}$-value $=0,038$ (one-tailed)

This finding may indicate some support for Lewicki and Bunker's (1996) argument that knowledge is an important factor in the escalation of trust. Employees on the higher levels may be more exposed to top management during their day-to-day activities at the company and consequently would be in a better position to gather first-hand knowledge of top management than employees on the more junior grades. However, a great deal more empirical research would need to be undertaken on this finding before any claim could be made. At best it only suggests an area for further research, particularly research of a qualitative nature.

The effects of change on age group

Regarding the management of change and the unfolding of change at the company it was found that, on both scales C1Management of change and C2-Unfolding of change, there was a significant difference in respect of age groups and that employees over the age of 52 years were inclined to be more positive about both the management and the unfolding of change than younger employees were. These results are illustrated in tables 7 and 8 . The results also suggest that the middle age groups tend to be the least positive about the management and unfolding of change at the company.

TABLE 7

Perceptions of management of Change and age

\begin{tabular}{|c|c|c|c|c|c|c|}
\hline \multicolumn{7}{|c|}{ Scale C1-Management of change } \\
\hline \multicolumn{3}{|c|}{$\mathrm{F}=4,417 \mathrm{p}=0,002$ ** } & \multirow{2}{*}{$\begin{array}{l}36-45 \\
\text { years }\end{array}$} & \multirow{2}{*}{$\begin{array}{r}25-35 \\
\text { years }\end{array}$} & \multirow{2}{*}{$\begin{array}{l}46-51 \\
\text { years }\end{array}$} & \multirow{2}{*}{$\begin{array}{l}24 \text { or } \\
\text { younger }\end{array}$} \\
\hline Age & $\mathbf{N}$ & Mean & & & & \\
\hline $36-45$ years & 155 & 2,8823 & & & & \\
\hline $25-35$ years & 143 & 3,0047 & 0,770 & & & \\
\hline $46-51$ years & 83 & 3,0331 & 0,736 & 0,999 & & \\
\hline 24 or younger & 16 & 3,1354 & 0,824 & 0,982 & 0,994 & \\
\hline 52 or older & 89 & 3,3146 & $0,002 * *$ & 0,074 * & 0,238 & 0,950 \\
\hline
\end{tabular}

${ }^{*} \mathrm{p}<0,1 * * \mathrm{p}<0,01$ 
TABLE 8

Perceptions of Unfolding of Change AND Age

\begin{tabular}{|c|c|c|c|c|c|c|}
\hline \multicolumn{7}{|c|}{ Scale C2-Unfolding of change } \\
\hline \multicolumn{3}{|c|}{$\mathrm{F}=3,000 \mathrm{p}=0,018^{*}$} & \multirow{2}{*}{$\begin{array}{l}36-45 \\
\text { years }\end{array}$} & \multirow{2}{*}{$\begin{array}{r}25-35 \\
\text { years }\end{array}$} & \multirow{2}{*}{$\begin{array}{l}46-51 \\
\text { years }\end{array}$} & \multirow{2}{*}{$\begin{array}{c}24 \text { or } \\
\text { younger }\end{array}$} \\
\hline Age & $\mathrm{N}$ & Mean & & & & \\
\hline $36-45$ years & 184 & 3,2671 & & & & \\
\hline $46-51$ years & 94 & 3,2675 & 1,000 & & & \\
\hline 24 or younger & 17 & 3,3361 & 1,000 & 1,000 & & \\
\hline 25-35 years & 163 & 3,3471 & 0,954 & 0,992 & 1,000 & \\
\hline 52 or older & 97 & 3,5405 & 0,004 * * & $0,047^{*}$ & 0,931 & $0,085 \phi$ \\
\hline
\end{tabular}

${ }^{*} \mathrm{p}<0,01{ }^{*} \mathrm{p}<0,05 \phi \mathrm{p}<0,1$

Although at first glance this finding may seem somewhat surprising, as it is often argued that older people are less inclined to accept change than younger people, it must be noted that older employees largely hold the more senior positions. Consequently, these more senior employees would tend to have greater control over the management and unfolding of change than their more junior colleagues. Secondly, many of the older employees, who may have had longer service than their younger colleagues, would be closer to retirement age and, as a result, could accept early retirement. People in the middle age group are the most vulnerable to change as they are affected the most in terms of their career and family cycles. These findings cannot be taken out of context and consequently only have limited application.

\section{CONCLUSION}

The findings in this research must be considered in the light of the various limitations that are inherent in what is a rather opportunistic study. In the first instance the researchers were restricted to using survey instruments that could not be changed as they met certain company requirements. Secondly, at the time of the second survey, the company had commenced what was to become a process of major restructuring. The changes that this restructuring brought about, even in the initial stages, possibly had some effect on the data collected. Thirdly, the timing of the study was not ideal as it rode on certain management needs at a particular point. It would have been more ideal to undertake this study at a later stage during the change process. However, this opportunity does not exist at this point and it is also unlikely to arise in the future, as the project is running way behind schedule and not entirely to plan. Thus management is extremely sensitive to any criticism that research may initiate.

Notwithstanding the limitations of this study, the results seem to indicate that all employees do not necessarily regard organisational restructurings as negative. This supports Mishra and Spreitzer's (1998) argument that not all survivors of restructurings will necessarily react negatively to these changes. Mishra and Spreitzer (1998) argue that some survivors seem to regard such change as an opportunity for growth while others may be quite neutral towards the restructuring, depending on how they believe that the organisational changes will affect them. In another vein, this research also seems to indicate that knowledge gathered by the trusting party, on the focus of trust, is indeed an influential factor in the formation of trust based relationships as has been suggested by Lewicki and Bunker (1996). It also seems that trust on an individual level, and trust at a more generalised level, operates independently.
However, what is probably most clear is that a great deal more empirical research is required before any clear picture of the impact of restructuring on trust will begin to emerge. It would be important for researchers to consider the contextual nature of trust and to gather information from different social settings, which is likely to enhance our understanding of the dynamics of trust. The nature of trust is such that it also lends itself to more qualitative research methods.

\section{REFERENCES}

Andrew Levy \& Associates. (2000). The 18th Annual report on labour relations in South Africa. Johannesburg: Andrew Levy $\&$ Associates.

BBC News. (1999). Education university shake-up leads to job cuts. http://news.bbc.co.uk/hi/english/education/newsid_342000/ 342957.stm (08/02/2000).

Bews, N.F. (1999). A sociological analysis of the concepts "PostIndustrial" and "Post-modern" and their effect on the notion of employer-employee trust. Unpublished Master's dissertation, Rand Afrikaans University, Johannesburg.

Bews, N.F. (2000). An investigation into the facilitators of the trustworthiness of managers. Unpublished Doctoral thesis, Rand Afrikaans University, Johannesburg.

Brenkert, G.G. (1998a). Trust, business and business ethics: An introduction. Business Ethics Quarterly, 8 (2), 195-203.

Brenkert, G.G. (1998b). Trust, morality and international business. Business Ethics Quarterly, 8 (2), 293-317.

Cleary, P. (1997, October 20). Lost jobs - The downsizing of Australia. Sydney Morning Herald.

Crandall, N.F. \& Wallace, M.J. (1998). Work and rewards in the virtual workplace: A new deal for employers and employees. New York: American Management Association.

Davis, J.H., Mayer, R.C. \& Schoorman, F.D. (1995). The trusted general manager and firm performance: Empirical evidence of a strategic advantage. Paper presented at the Annual Meeting of the Strategic Management Society, Mexico City.

Denny, C. \& Treanor, J. (1998). Survey of managers predicts soaring job losses. Guardian On Line. http://www.thisisthenortheast. co.uk/ne/echo/jobs/report4.htm (08/02/2000).

Dibben, M.R. (2000). Exploring interpersonal trust in the entrepreneurial venture. London: MacMillan.

Engelbrecht, A.S. \& Cloete, B.E. (2000). An analysis of a supervisor-subordinate trust relationship. Journal of Industrial Psychology, 26 (1), 29-38.

Handy, C.B. (1994). The age of paradox. Boston: Harvard University Press.

Hay, A. (Forthcoming). Trust and organisational change: An experience from manufacturing. Journal of Industrial Psychology, In press.

Horton, R.T. \& Reid, P.C. (1991). Beyond the trust gap forging a new partnership between managers and their employers. Homewood,ILL: Business One Irwin.

Howard, A. (Ed.) (1996). The changing nature of work. San Francisco: Jossey-Bass.

Husted, B.W. (1998). The ethical limits of trust in business relations. Business Ethics Quarterly, 8 (2), 233-248.

Kramer, R.M., \& Tyler, T.R. (Eds.) (1996). Trust in organisations. Frontiers of theory and research. Thousand Oaks, CA: Sage.

Kyoko, C. (1996). Coping with freedom: Can the salaryman change his spots? Tokyo Business Today, 64 (1), 28-31.

Lewicki, R.J. \& Bunker, B.B. (1996). Developing and maintaining trust in work relationships. In R.M. Kramer \& T.R. Tyler (Eds.). Trust in organisations: Frontiers of theory and research. Thousand Oaks, CA: Sage.

Martins, N. Watkins, M., Von der Ohe, H. \& De Beer, M. (1997). Trust audit summary report. Pretoria: Centre for Industrial and Organisational Psychology, Department of Industrial Psychology, University of South Africa. 
Mayer, R.C., Davis, J.H., \& Schoorman, F.D. (1995). An integrative model of organisational trust. Academy of Management Review, 20 (3), 709-734.

Mishra, A.K. (1996). Organisational responses to crisis. The centrality of trust. In R.M. Kramer \& T.R. Tyler (Eds.). Trust in organisations: Frontiers of theory and research. Thousand Oaks, CA: Sage.

Mishra, A.K. \& Spreitzer, G.M. (1998). Explaining how survivors respond to downsizing: The role of trust, empowerment, justice and work redesign. Academy of Management Review, 23(3).

Powell, W.W. (1996). Trust-based forms of governance. In R.M. Kramer \& T.R. Tyler (Eds.). Trust in organisations: Frontiers of theory and Research. Thousand Oaks, CA: Sage.

Reina, D.S. \& Reina, M.L. (1999). Trust and betrayal in the workplace: Building effective relations in your organisation. San Francisco: Berrett-Koeler.
Robbins, S. P. 2001. Organisational behaviour. Prentice Hall: New Jersey

Rossouw, G.J. \& Bews N.F. (2001). Building trust with ethics. In G.J. Rossouw. Business ethics: Made in Africa. Cape Town: Oxford University Press.

Shaw, R.B. (1997). Trust in the balance: Building successful organisations on results, integrity, and concern. San Francisco: Jossey-Brass.

Soule, E. (1998). Trust and managerial responsibility. Business Ethics Quarterly, 8 (2), 249-272.

Thomas, A. (1996). Beyond affirmative action: Managing diversity for competitive advantage in South Africa. Randburg: Knowledge Resources.

Webster, F. (1995). Theories of the information society. London: Routledge. 